\title{
Metal influence on metallothionein synthesis in the hydrothermal vent mussel Bathymodiolus thermophilus
}

\section{Yann HARDIVILLIER ${ }^{1}$, Françoise DENIS ${ }^{1}$, Marie-Véronique DEMATTEI ${ }^{2}$, Paco BUSTAMANTE ${ }^{3}$, Marc LAULIER ${ }^{1}$ and Richard COSSON ${ }^{4}$}

${ }^{1}$ Laboratoire de Biologie et Génétique Evolutive, Université du Maine, Avenue Olivier Messiaen 72085 Le Mans, France

${ }^{2}$ Laboratoire d'Etude des Parasites Génétiques, Université François Rabelais, E.A.3868, UFR des Sciences et Techniques, Parc de Grandmont, Avenue Monge, 37200 Tours, France

3 Laboratoire de Biologie et Environnement Marins, FRE 2727 du CNRS, Université de La Rochelle, 22 Avenue Michel Crépeau, F-17042 La Rochelle, France

${ }^{4}$ ISOMer-UPRES-EA 2663 Laboratoire de Biologie Marine, Université de Nantes, BP 92208 F44322 Nantes CEDEX 3, France

Corresponding author: Yann.Hardivillier@univ-lemans.fr

Running title: Metallothionein expression in Bathymodiolus thermophilus 


\begin{abstract}
The present study reports on the metallothionein expression in the hydrothermal vent mussel Bathymodiolus thermophilus. Metallothioneins (MT) are proteins involved in intracellular metal regulation and conserved throughout the animal kingdom. The hydrothermal vent environment presents peculiarities (high levels of sulfides and metals, low $\mathrm{pH}$, anoxia) that may have driven associated species to develop original evolutionary ways to face these extreme living conditions. Mussels were exposed to different metal solutions at the atmospheric pressure. The MT mRNA levels and MT contents were measured in gills and mantles of each exposed mussel. The intracellular metal distribution was estimated in fractions obtained after the centrifugation of tissue homogenates. A few of the tested metals ( $\mathrm{Ag}, \mathrm{Cu}, \mathrm{Cd}, \mathrm{Hg}$ and $\mathrm{Zn}$ ) were able to significantly induce MT mRNA levels. Silver was the only one that produced a significant increase of the MT protein level in both mantle and gills. The gills always presented higher MT protein levels than the mantle did, while their MT mRNA levels were similar. Our data show that MT mRNA and MT protein levels do not follow a clear relationship in the gills and mantle of $B$. thermophilus and we assume that a post-transcriptional control occurs in these mussels.
\end{abstract}

Keywords: Bathymodiolus; Bivalvia; Gene expression; DNA; Hydrothermal; Metabolism; Metal; Metallothionein; Protein; RNA 


\section{Introduction}

Hydrothermal vents were discovered by the end of the seventies (Lonsdale, 1977). The magma source and surrounding sea water interactions produce hot fluids that are dispersed in the hydrothermal environment. These fluids are characterized by a low $\mathrm{pH}$, high hydrogen sulfide and metal concentrations as well as anoxia (Sarradin et al., 1999; Geret et al., 2002). High concentrations of cadmium $(\mathrm{Cd})$ and copper $(\mathrm{Cu})$ may impact biological processes at the endemic fauna level. The reported ratio between $\mathrm{Cu}$ concentrations in surface water and hydrothermal environment is about one thousand (Douville et al., 2002). Bathymodiolus thermophilus is a common bivalve (Mytilidae) of the Pacific Ocean hydrothermal vent ecosystems (Desbruyeres et al., 2001). These mussels may have developed a high tolerance or some adaptive strategies to live in these peculiar environments (Sarradin et al., 1999).

Metallothioneins (MTs) are small, cysteine rich, metal storage proteins conserved throughout the animal kingdom and involved in intracellular metal regulation. Their participation in metal detoxication is well established (Geret et al., 1998; Cajaraville et al., 2000). Beside these roles, MTs protect cells against damage induced by alkylating agents, oxygen radicals and ionizing radiations (Cherian et al., 1994). Discovered over four decades ago (Margoshe and Vallee, 1957), they are characterized by selectively metal binding affinities which allow the use of MTs as molecular probes (biomarkers) in environmental biomonitoring (Hennig, 1986). Not all biological functions of MTs are clearly resolved but the existence of different isoforms may suggest that they have distinct roles. Two major isoforms have been identified in Mytilidae: MT10 and MT-20 (Mackay et al., 1993; Hardivillier et al., 2004). The MT-10 isoform appears to be involved in the regulation of free intracellular metal content in Mytilus edulis and is constitutively expressed at a basal level, whereas MT-20 production seems to be specifically induced by Cd (Dallinger, 1996; Lemoine and Laulier, 2003). Many studies describe MTs in coastal organisms (e.g. Amiard-Triquet et al., 1998; Barsyte et al., 1999; Engelken and Hildebrandt, 1999; Cotou et al., 2001; Serafim and Bebianno, 2001; Moraga et al., 2002; Mouneyrac et al., 2002; Berthet et al., 2003) but so far very few studies concern hydrothermal vent organisms (i.e. Cosson and Vivier, 1997; Denis et al., 2002; Leignel et al., 2004; Hardivillier et al., 2004).

The aim of our investigation was to study the metallothionein gene expression in B. thermophilus exposed to metals at the atmospheric pressure. A comparison with the reported MT expression in M. edulis (Lemoine et al., 2000) will permit us to show putative specificities of hydrothermal vent mussels. The study of MT synthesis regulation could help for understanding how hydrothermal mussels adapted to the presence of high concentrations of metals in their environment.

\section{Material and methods}

\section{- 2.1 Experimental exposure of bivalves}

Vent mussels (B. thermophilus) were collected during the HOPE 99 hydrothermal cruise (Chief Scientist: F. Lallier) on the EPR at the site named BioVent (N 09 $46^{\prime}-\mathrm{W} 104^{\circ} 21^{\prime}-2516 \mathrm{~m}$ depth) with the manned submersible "Nautile" deployed from the oceanographic research vessel "L'Atalante" (IFREMER). Groups of 4 individuals were transferred to $10 \mathrm{~L}$ aquaria containing surface sea water enriched with various metals $\left(\mathrm{Cd}\right.$ in the form of $\mathrm{CdNO}_{3}, \mathrm{Cu}$ in the form of $\mathrm{CuNO}_{3}, \mathrm{Hg}$ in the form of $\mathrm{HgNO}_{3}, \mathrm{Zn}$ in the form of $\mathrm{ZnNO}_{3}$, each in $\mathrm{H}_{2} \mathrm{SO}_{4}$ and $\mathrm{Ag}$ in the form of $\mathrm{AgNO}_{3}$ in $\mathrm{HNO}_{3}$ ). The molluscs were exposed to mono-metallic solutions (Merck) (Ag, $\mathrm{Cd}$, 
$\mathrm{Cu}, \mathrm{Hg}$ and $\mathrm{Zn}$ respectively 20; 200; 40; 20 and $1000 \mu \mathrm{g} \mathrm{L}^{-1}$ ) for $44 \mathrm{~h}$ at atmospheric pressure. Controls were maintained in the same conditions in clean seawater. No mortality was recorded during the experiment. At the end of the exposure period, gills and mantle were excised and immediately frozen in liquid nitrogen for further analysis. Specifically in order to compare the DNA sequences of the Pacific mussel with an other related species, Bathymodiolus azoricus were collected at the site named Lucky Strike (N 37 $13^{\prime}$, W 32 $2^{\circ} 19^{\prime},-1700 \mathrm{~m}$ depth) in the Azores region (Mid-Atlantic Ridge) during the ATOS cruise (Chief Scientist: P.M. Sarradin-RV "L'Atalante"-ROV "Victor 3000"-IFREMER) by 2001. As for Pacific mussels, excised tissues were immediately frozen in liquid nitrogen when taken onboard and stored until required.

\section{- $\quad$ 2.2 Metal analysis}

Tissue samples were homogenized in 5 volumes of buffer $(100 \mathrm{mM}$ Tris, $\mathrm{pH} 8.1,10 \mathrm{mM} \beta$ mercaptoethanol). Homogenates were centrifuged for $30 \mathrm{~min}$ at $30000 \mathrm{~g}$ at $4{ }^{\circ} \mathrm{C}$. An aliquot of each supernatant was kept at $-80{ }^{\circ} \mathrm{C}$ until the determination of the total protein content. A second aliquot was submitted to heat-denaturation $\left(95^{\circ} \mathrm{C}, 15 \mathrm{~min}\right)$ and centrifuged $(10000 \mathrm{~g}, 15$ $\mathrm{min}$ ) in order to separate the thermostable metallothioneins from thermolabile proteins. Newly obtained supernatants were frozen at $-80{ }^{\circ} \mathrm{C}$ until the quantification of MTs. The content of tested metals ( $\mathrm{Ag}, \mathrm{Cd}, \mathrm{Cu}, \mathrm{Hg}, \mathrm{Zn}$ ) in control and corresponding exposed mussel tissues was determined by atomic absorption spectrophotometry (AAS) after acidic digestion with nitric acid in the supernatants and pellets of the first centrifugation Complementary analyses of essential metals $(\mathrm{Cu}, \mathrm{Zn})$ were also performed in both fractions resulting from the centrifugation of homogenized non-essential ( $\mathrm{Ag}, \mathrm{Cd}, \mathrm{Hg}$ ) exposed mussel tissues. Blanks and reference materials (NRCC) were taken through the procedure in the same way as the samples. Levels of metals are given relatively to the wet weight of tissues.

\section{- $\quad 2.3$ MT mRNA analysis}

The total RNA was isolated from each sample according to the classic acid-guanidium thiocyanate-phenol-chloroform extraction method (Chomczynski and Sacchi, 1987). Briefly, tissues were ground to a fine powder using a mortar and a pestle in liquid nitrogen and then homogenized in an acid guanidium thiocyanate buffer. They were mixed thoroughly with $3 \mathrm{M}$ sodium acetate and extracted with phenol/chloroform/iso-amyl alcohol (Genaxys). After centrifugation at $10000 \mathrm{~g}$ for $20 \mathrm{~min}$, the aqueous phase was precipitated with 2-propanol at $-20{ }^{\circ} \mathrm{C}$ during $30 \mathrm{~min}$. The RNA was finally pelleted by centrifugation and washed twice in $70 \%$ ethanol before being dissolved in diethyl pyrocarbonate (DEPC)-treated water, and stored at $-80{ }^{\circ} \mathrm{C}$. Purity and integrity of the samples were confirmed by gel electrophoresis and ethidium bromide staining. MT gene expression was analysed by dot blot hybridizations with MT-10 or MT-20 mRNA probes (Hardivillier et al., 2004). Actin-1, 28S, and histone-4 templates were used to generate $32 \mathrm{P}$ labelled probes employed for standardisation. Ten micrograms of each RNA sample were mixed with $20 \mu \mathrm{L} 100 \%$ formamide, $7 \mu \mathrm{L} 37 \%$ formaldehyde and $2 \mu \mathrm{L} 20 \times \mathrm{SSC}$, heated at $68{ }^{\circ} \mathrm{C}$ for $15 \mathrm{~min}$ and immediately cooled on ice. RNA samples were transferred to positively charged nylon blotting membranes (Amersham) using a dot-blot apparatus. RNA was immobilized on the membranes by heating at $80{ }^{\circ} \mathrm{C}$ during $2 \mathrm{~h}$. Specificity of hybridization conditions was optimized using blots of cDNA prepared from each analysed gene. Prehybridization was done at $42{ }^{\circ} \mathrm{C}$ for $2 \mathrm{~h}$ in $50 \%$ formamide, $1 \%$ SDS, 1 $\mathrm{M} \mathrm{NaCl}$ and $10 \mu \mathrm{g} \mu \mathrm{L}-1$ denatured salmon sperm DNA. Probe labelling reactions were performed at $37{ }^{\circ} \mathrm{C}$ for $10 \mathrm{~min}$ in a mixture containing reaction buffer, random decamers, deionized water, dCTP, dTTP, dGTP, $\alpha 32 \mathrm{P}-\mathrm{dATP}$ and Klenow fragment in a final volume of 50 $\mu \mathrm{L}$ according to the Manufacturer's instructions (Fermentas). The reaction was stopped by 
adding EDTA. Unincorporated nucleotides were removed using Sephadex G-50 columns. Each radioactive probe was synthesized at the

same time from a single lot of 32P to allow their level comparisons because of their close adenine content. Hybridization with the labelled probe was done overnight $(12-16 \mathrm{~h})$ at $42{ }^{\circ} \mathrm{C}$ in the buffer mentioned above. All hybridizations were carried out under the same conditions. Membranes were washed sequentially in $2 \times, 1 \times$ and $0.5 \times$ SSC solutions $(30 \mathrm{~min})$ at $42{ }^{\circ} \mathrm{C}$. Blots were then exposed to an Instant Imager (PACKARD) for quantification of gene expressions. Between each hybridization, membranes were dehybridized by incubating $30 \mathrm{~min}$ in boiling $1 \%$ SDS. Radioactivity counting was performed as a control.

\section{- $\quad$ 2.4 Expression standard (Actin-1, histon-4, 28S gene)}

The quantification of the metallothionein gene expression has to be standardised by comparing its level with those of other genes that are considered as stable and non-interfering with the metal detoxification processes. The chosen ones were actin-1, histone- 4 and $28 \mathrm{~S}$ genes.

Complementary DNA (cDNA) was synthesized using approximately $5 \mu \mathrm{g}$ of total RNA. Oligo(dT)20 primers were added and then put to a final volume of $12 \mu \mathrm{L}$ with DEPC treated water. This mixture was denatured at $70{ }^{\circ} \mathrm{C}$ for $5 \mathrm{~min}$ and put on ice to allow the primers to anneal to the template. Samples were reverse transcribed for $90 \mathrm{~min}$ at $42{ }^{\circ} \mathrm{C}$ with Moloney Murine Leukemia Virus Reverse Transcriptase (MMLV RT®, Promega), RNAse inhibitor (RNAsin ${ }^{\circledR}$, Promega) and dNTPs in a reaction volume of $25 \mu \mathrm{L}$. The reaction was stopped incubating $5 \mathrm{~min}$ at $68{ }^{\circ} \mathrm{C}$. The resulting reverse transcribed products were used for PCR amplification performed with a set of specific oligonucleotide primers for actin-1, histone-4 and $28 \mathrm{~S}$ gene (Fig. 1). Polymerase chain reactions were performed with Taq polymerase ${ }^{\circledR}$ (Promega), buffer, primers, dNTPs and nuclease-free water in a final volume of $25 \mu \mathrm{L}$. The thermal cycling program on a minicycler thermocycler ${ }^{\circledR}$ (Eppendorf) was set as follows: 35 cycles of $1 \mathrm{~min}$ at $94{ }^{\circ} \mathrm{C}$ (denaturing phase), $1 \mathrm{~min}$ at $57{ }^{\circ} \mathrm{C}$ for actin- $1,53{ }^{\circ} \mathrm{C}$ for histone- 4 and $57{ }^{\circ} \mathrm{C}$ for $28 \mathrm{~S}$ (annealing phase), and $1 \mathrm{~min}$ at $72{ }^{\circ} \mathrm{C}$ (elongation phase) followed by a single cycle at $72{ }^{\circ} \mathrm{C}$ for $10 \mathrm{~min}$.

PCR products were separated by gel electrophoresis and ethidium bromide staining. Bands of the expected size were excised under UV light and purified using the WIZARD SV gel and PCR clean up system (Promega) according to the Manufacturer's instructions. Purified products were ligated into the pGEM-T easy vector system I (Promega) with T4 DNA ligase. Escherichia coli JM109 high efficiency competent cells (Promega) were transformed with $10 \mu \mathrm{L}$ of the ligation mixture and plated on ampicillin plates with Xgal and IPTG. Individual colonies were screened by PCR using the primers mentioned above.

Insert-containing plasmids were purified using the Wizard plus Minipreps DNA purification System (Promega) according to the manufacturer's instructions. They were sequenced on a fluorescent automated sequencer from both $5^{\prime}$ and $3^{\prime}$ ends with the ABI PRISM Dye Terminator Cycle Sequencing Ready Reaction Kit (Perkin Elmer, USA).

Nucleic sequences of $B$. azoricus and $B$. thermophilus were manually inspected and vector sequences were edited out. Forward and reverse sequences were aligned after editing with a multiple sequence alignment tool ClustalW (version 1.83) (Thompson et al., 1994). Expasy translate tool software was used to translate the nucleic acid sequence in all potential reading frames. Characterization searching was performed, using the BLAST program (Altschul et al., 1990), using the nucleic acid and predicted amino acid sequence to compare the sequences to others deposited in multiple databases.

\section{- 2.5 Protein analysis}


Total protein levels of the crude supernatant were measured by the Lowry method (Lowry et al., 1951). The protein levels were calculated using BSA (bovine serum albumin) as reference material and expressed as mg of protein (BSA equivalent) per $\mathrm{g}$ of wet mass of tissue (mg. $\mathrm{g}^{-1}$ w.wt.).BSA equivalent) per g of tissue wet weight (mg.g ${ }^{-1}$ w.wt.).

The levels of MT in heat-denatured supernatants were estimated by differential pulse polarography (DPP) (Olafson and Sim, 1979, improved by Thompson and Cosson, 1984). A calibration curve was obtained by the standard addition method, using rabbit liver metallothionein (SIGMA, M-7641) as reference material. All the reagents used did not give a polarographic signal during the dosage of MT (Erk and Raspor, 2000). Levels of MT are given relative to the wet mass of tissue ( $\mathrm{mg} \mathrm{g}^{-1}$ w.wt.).

\section{- 2.6 Statistics}

The data represent means \pm S.D. Differences between treatment groups were evaluated by Kruskal-Wallis nonparametric tests followed by Mann-Whitney tests when a significant difference was detected $(\mathrm{P} \leq 0.05)$. All statistics were performed using Sigma Stat 2.0 software.

\section{Results}

\section{- 3.1 Expression standard isolation (Actin-1, Histone-4, 28S gene)}

Total RNAwas extracted from both species (B. thermophilus and B. azoricus) and was reverse transcribed. Fragments of each standard were isolated from $B$. azoricus and $B$. thermophilus.

An actin-1 cDNA fragment of approximately $300 \mathrm{bp}$ was amplified by PCR from both species, cloned in the pGEM-T easy vector system I and sequenced. Inserts presented an actin-1 fragment of 275 bp long and nearly identical for both species except for two silent mutations at positions 129 and 231 (99\% homology). A manual verification of the chromatograms corroborated the sequences. These two cDNA fragments also present strong nucleotide homology with other bivalve actin-1 sequences (Fig. 2): 95\% with Mytilus galloprovincialis (accession no. AF157491), 91\% with Crassostrea gigas (accession no. AB071191), 90\% with Placopecten magellanicus (accession no. U55046) and $85 \%$ with Crassostrea virginica (accession no. X75894). The B. azoricus and the $B$. thermophilus Actin-1 sequences were deposited in EMBL under accession nos. AJ786402 and AJ786403.

A similar strategy was used to isolate a fragment of the histone-4 gene in both mussel species (Fig. 3). Fragments of 251 bp were cloned from both species and found nearly identical except for five mutation sites at positions 38, 45, 75, 165 and 217 (98\% homology). These mutations are all silent except for that at position 38 . Both histone gene fragments were translated in silico and the proteins showed a substitution of the lysine at position 13 by a glutamine residue. The histone- 4 cDNA fragments show $84 \%$ homology with histone-4 in M. edulis (accession no. AJ492925) which confirms the evolutionary relationship between the hydrothermal vent mussels and M. edulis. The B. azoricus and the $B$. thermophilus Histone-4 sequences were deposited in EMBL under accession no. AJ786405 and no. AJ786404. The sequences of the histone-4 fragments that were isolated in both Bathymodiolus species present more variations with the histone-4 of M. edulis than the actin-1 fragments of the blue mussel. 
A $274 \mathrm{bp}$ fragment of the $28 \mathrm{~S}$ gene was amplified in both hydrothermal vent mussel species by PCR. The two sequences are completely identical underlining the highly related nature of the two species (Fig. 4). These fragments present strong nucleotide homology with other bivalve $28 \mathrm{~S}$ genes: $98 \%$ with $M$. edulis (accession no. AF120587) and $M$. galloprovincialis (accession no. AB103129), and 96\% with Modiolus nipponicus (accession no. AB103125). The B. azoricus and the B. thermophilus $28 \mathrm{~S}$ sequences were deposited in EMBL under accession nos. AJ786406 and AJ786407.

\section{- 3.2 Metal distribution}

The exposures of $B$. thermophilus for $44 \mathrm{~h}$ result in an increase of total levels of $\mathrm{Ag}, \mathrm{Cd}$ and $\mathrm{Zn}$ in the gills and the mantle relatively to the levels measured in both organs of control mussels (Table 1). Conversely, it seems that no uptake of $\mathrm{Cu}$ and $\mathrm{Hg}$ resulted from the exposure of mussels to these metals in the time course of the experiment.

The subcellular elemental distribution of $\mathrm{Cu}$ and $\mathrm{Zn}$ in the gills and the mantle of $B$. thermophilus is given in Fig. 5 for control and exposed mussels.

The exposure to $\mathrm{Ag}$ resulted in a significant increase of $\mathrm{Zn}$ level in the soluble fraction of the gills, while $\mathrm{Cu}$ levels increased in both soluble and insoluble fractions of the same tissue. The exposure to $\mathrm{Cd}$ resulted in significant increases of $\mathrm{Cu}$ and $\mathrm{Zn}$ levels in the soluble fractions of the gills, and of $\mathrm{Cu}$ in the insoluble fraction of the mantle while $\mathrm{Zn}$ increased in the soluble fraction of the latter organ. The exposure to $\mathrm{Cu}$ resulted in increases of $\mathrm{Cu}$ in both fractions of the gills associated with an increase of $\mathrm{Zn}$ in the soluble fraction. In the same time, $\mathrm{Cu}$ decreased significantly in the insoluble fraction of the mantle. The exposure to $\mathrm{Zn}$ resulted in an increase of $\mathrm{Cu}$ levels in the soluble fraction of the gills and a decrease in the insoluble fraction of the mantle, while $\mathrm{Zn}$ increased in both fractions in the gills but only in the soluble fraction in the mantle.

\section{- $\quad 3.3$ Levels of MT mRNA}

Normalised levels of MT-10 and MT-20 mRNAs were detectable in gills and in the mantle of untreated and treated B. thermophilus all over the exposure experiments (Fig. 6).

The expression of both isoforms appeared to be stable and was not significantly induced in a metal-dependent manner. Statistical analysis shows that there was no significant difference $(\mathrm{P}>0.05)$ between MT mRNA levels of untreated and treated mussels. Standard deviations were low and express the little variation between individuals within each tested condition. This supports the hypothesis of the absence of induction of the metallothionein gene.

Gills and mantle presented the same behaviour. No significant differences were observed between the MT mRNA levels within these two organs ( $\mathrm{P}>0.05)$.

The MT-20 mRNA levels were always detected higher than those of the MT-10 mRNA. The MT mRNA expression was standardised by the signal of an actin-1, a histone-1 and a $28 \mathrm{~S}$ probe. Each standard level remained constant all over the mussel treatments. The standard deviations of the $28 \mathrm{~S}$ were greater than those obtained with the two other standards. This underlines the superior inter-individual variability of the transcriptional activity of the $28 \mathrm{~S}$ gene.

\section{- 3.4 Levels of MT proteins}

MT contents in both studied organs of control or exposed B. thermophilus are presented in Fig. 7. MT levels were always significantly $(\mathrm{P}<0.05)$ higher in the gills than in the mantle. 
The statistical analysis showed that silver was the only metal able to produce a significant increase of the MT level between exposed and control mussels after $44 \mathrm{~h}$ of experiment. This increase was associated to low standard deviations. It was detected in the gills and in the mantle corresponding to respective enhancements of $14 \%$ and $66 \%$. The mantle did not show any significant increase following the exposure to other metals. $\mathrm{Cu}, \mathrm{Hg}$ and $\mathrm{Zn}$ produced a significant decrease of MT levels (respectively $-37 \%,-44 \%$ and $-46 \%$ ) comparatively to the level of MT in the gills of control mussels. Even if no mortality occurred, experimental conditions, particularly pressure variations, may have induced cellular perturbations that would have been able to produce these decreases. Kruskal-Wallis test showed no significant differences between the levels of MT in both organs of Cd-exposed and control mussels.

\section{- 4. Discussion}

Our study reports on variations of MT protein and MT mRNA syntheses in the gills and mantle of the hydrothermal vent mussel $B$. thermophilus following a short exposure to monometallic solutions. This was performed to trigger MT gene induction by the uptake of tested metals and especially by the modification of their subcellular distribution taking into account that MTs are metal-induced soluble metalloproteins.

Overall, gills have a major importance in the bioaccumulation of metals in Mytilidae (Roméo et al., 2005). In control, the gills of $B$. thermophilus exhibited higher metal levels than that observed for the mantle, confirming the observations reported by Rousse et al. (1998) on $B$. azoricus from the Mid-Atlantic Ridge. This higher content results from their large interface with the hydrothermal environment and their involvement in respiration and nutrition (CossonMannevy et al., 1988; Langston et al., 1998; Marigomez et al., 2002). The mantle is responsible for the synthesis of the shell of the bivalve molluscs and has a lesser importance in the uptake and storage of metals. Beside a short duration ( $44 \mathrm{~h}$ ) the exposure to $\mathrm{Ag}, \mathrm{Cd}$ and $\mathrm{Zn}$ resulted in an increase of the total content of respective metals in the gills and mantle of exposed mussels. The lack of observed uptake of $\mathrm{Cu}$ and $\mathrm{Hg}$ after the exposure may be related to a poorly available chemical form of these metals in the experimental solutions. Another factor likely to interfere with a normal behaviour of the mussels in the presence of metals is the stress due to the collection on the bottom of the ocean by $2500 \mathrm{~m}$ depth and the fact that the experiment was performed at the atmospheric pressure.

The subcellular distribution of $\mathrm{Cu}$ and $\mathrm{Zn}$ varies with the considered element and tissue. Copper was more abundant in the insoluble fraction of both gills and mantle, while $\mathrm{Zn}$ was mainly found in the soluble fraction of the gills and equally distributed in the mantle. This pattern is frequently observed in bivalves (Duquesne and Coll, 1995; Rousse et al., 1998; Canesi et al., 1999; Geret, 2000; Geffard et al., 2005).

In the marine invertebrate, Nereis diversicolor, $\mathrm{Cu}$ is more bound to the insoluble fraction when individuals are collected from $\mathrm{Cu}$ contaminated areas than from non-contaminated areas (Berthet et al., 2003). Hydrothermal vent environment is known to have elevated concentrations of $\mathrm{Cu}$ (Douville et al., 2002; Kadar et al., 2006). The high level of $\mathrm{Cu}$ found in the insoluble fraction of both organs of the hydrothermal mussels is convenient with the pattern observed in $N$. diversicolor. Copper is an essential element required for the biological function of numerous proteins including hemocyanins which are efficient dioxygen transporting molecules in Mollusca. The high level of $\mathrm{Cu}$ in the insoluble fraction may be attributed to degraded forms of these molecules that would have been transferred into lysosomes, the organelle that is able to sequester metals under insoluble form (Viarengo et al., 1988). The larger proportion of zinc in the soluble fraction has to be related to its involvement in the structure of numerous thermostable (e.g. MTs) and thermolabile proteins (Bustamante and Miramand, 2004).

When the exposure to a single metal was followed by an increase of the total level of this metal and/or a modification of the distribution of essential metals (e.g. an increase of zinc in the 
soluble fraction) we could expect to observe a correlated activation of the MT gene transcription and an increase of MT protein level in the concerned tissue.

Metallothioneins are proteins involved in stress phenomena. Their induction by metals was firstly reported by Piscator (1964) and until today, studies of MT gene expression corroborated this postulate whatever the studied species (Olsson and Kille, 1997; Lam et al., 1998; Morris et al., 1999; Pedersen et al., 1994; Raspor et al., 1999; Sturzenbaum et al., 1998; Hensbergen et al., 2000). In M. edulis, nine isoforms were isolated and classified into two pools of protein, the MT10 and the MT-20 (Mackay et al., 1993). It was suggested that the presence of such a number of isoforms may reflect different metal binding affinities and specificities of the promoters of the different genes. An analysis of MT gene expression was reported in M. edulis by Lemoine et al. (2000). They showed that blue mussel differentially expresses MT and suggested that the two MT pools were involved in different mechanisms implying that they may have different functions. The first pool including the MT-10 isoforms was constitutively synthesized and may be involved in the regulation of essential metals such as $\mathrm{Cu}$ and $\mathrm{Zn}$. The other pool including the MT-20 isoform was induced by $\mathrm{Cd}$ and could be implicated in detoxifying processes. Results presented in this work do not fit with this previous report on littoral mussels. Contrary to other studies on MT gene expression in mytilids (George, 1983; Viarengo et al., 1985; Lemoine et al., 2000), there is no apparent induction of transcription and translation of the MT genes by each of the tested metals in hydrothermal mussels under our experimental conditions. Results of exposed mussels were nearly identical with controls. Whatever exposure resulted in the same pattern of MT gene expression: the responses of MT-10 and MT-20 genes remain constant.

The high basal MT-10 and MT-20 mRNA levels in unexposed mussels may indicate pre-existing MT mRNAs of both isoforms (Roesijadi and Hall, 1981; Viarengo et al., 1985). In our work, the pattern of the MT-20 gene expression is in contrast with that of the littoral blue mussel which does not show any MT-20 transcripts in non-exposed mussels (Lemoine et al., 2000). The response of the Bathymodiolus MT-20 gene was always higher than that of the MT-10 gene. This contrasts with the behaviour of the MT genes reported in M. edulis which presents a constitutively synthesized MT-10 isoform whereas the MT-20 is induced by Cd (Lemoine et al., 2000). The comparison of MT gene expression in hydrothermal and littoral mussels underlines that two species belonging to the same family (Mytilidae) may present differences in relation with the disparities between their environments.

No difference of MT mRNA levels was denoted between the gills and the mantle of $B$. thermophilus (Fig. 6). In M. edulis, the gills present a higher MT gene expression than the mantle and the digestive gland tissues (Lemoine et al., 2000). Similar results were obtained by Denis et al. (2002) for hydrothermal mussels. This former work reported on a non-standardised expression of MT gene in Bathymodiolus sp. In our work, the response of MT genes in $B$. thermophilus does not seem to be organ specific underlying the major importance of the standardisation of the hybridization experiments by an outer gene probe considered as noninterfering in the metal metabolism.

The nature of the standard appears to be of great importance. Even if the transcriptional profiles of the three tested genes presented stable patterns, the sizes of the standard deviations were different. Both actin-1 and histone-4 signals presented tiny standard deviations while the $28 \mathrm{~S}$ profile showed more elevated ones. This underlines the fact that the inter-individual variability is greater for the expression of the $28 \mathrm{~S}$ gene than for the answer of the two other genes. The $28 \mathrm{~S}$ gene expression could vary in exposed mussels owing to an involvement in protein synthesis.

The hydrothermal ecosystem exhibits naturally high metal concentrations. Fluids which are emitted from hydrothermal vents are fully charged with polymetallic sulfurs that are dispersed into the water surrounding the molluscs (Sarradin et al., 1999). It implies that hydrothermal mussels may tolerate higher metal concentrations than the littoral blue mussel.

Gills shows higher levels of metals than the mantle which plays a less preponderant role in metal uptake (Mouneyrac et al., 1998) and MT synthesis is more important in gills, while there is no 
difference in the levels of MT mRNA between gills and mantle. These results suggest that different posttranscriptional controls of the MT synthesis may occur in these organs.

By analysing metal distribution, MT mRNA and MT protein in target tissues of untreated and treated animals, we hoped to provide further insight into MT inducibility. In this regard, bivalves, particularly mussels accumulate trace elements at often high levels, depending on the metal and the tissue (Langston et al., 1998). Clear variations in metal distribution and in MT expression could have been identified but our study showed complex profiles of metal distribution and MT expression. A lack of correlation between the metal concentrations, the inducibility of MT mRNA and MT proteins was denoted. Although regulation of MT synthesis seems to occur at the transcriptional level (Haq et al., 2003), experimental evidence suggests that MT levels are regulated by the rate of protein degradation (Palmiter, 1995; Kershaw and Klaassen, 1992; McKim et al., 1992).

The possibility that MT genes may not have such an important role to play in B. thermophilus should as well be hypothesized. Bivalves are known to accumulate metals and Bathymodiolus was reported to have a high metal content (Rousse et al., 1998) but the low levels of metals bound to MT raised the question about their involvement in the metal detoxication processes (Fiala-Médioni et al., 2000). Bathymodiolus sp. houses symbiotic bacteria in vacuoles within the apical end of specialized gill cells called bacteriocytes (Fiala-Medioni et al., 1986). The symbiotic bacteria could play a fundamental role in the metal detoxication of metal. Marine åproteobacteria, for example, common bacteria of the hydrothermal vent sites, tolerate high concentration of Cd (Jeanthon and Prieur, 1990; Cottrell and Craig Cary, 1999). The absorption of metal ions by these bacteria by phenomena of ingestion, and the excretion of these metals under particulate forms unavailable to biota could decrease the toxicity of metals for the hydrothermal communities. The eventuality that symbiotic bacteria may interact with mussels to detoxify the organism cannot therefore be excluded.

The comparison of MT levels observed in hydrothermal and in littoral mussels emphasises great disparities. The amounts measured in M. edulis and in C. gigas (Geret, 2000) show that gills and mantle of these animals are characterized by smaller MT levels than that of hydrothermal mussels (Table 2). This could demonstrate that MT may have a major role in hydrothermal mussels. Their synthesis would not be as important if they were not fundamental for the cellular integrity.

The monometallic solutions used to expose the hydrothermal vent mussels were higher than that naturally occurring in their environment (Table 3). The exposure concentrations for $\mathrm{Cd}, \mathrm{Cu}$ and $\mathrm{Hg}$ were very high when compared to the natural conditions while the lowest ratio was for $\mathrm{Zn}$ as it is considered as the primary inducer of MT synthesis (Roesijadi, 1996). Nevertheless, hydrothermal mussels live in a diluted fluid and do not face concentrations as high as those used for our exposures.

When B. thermophilus were sampled and brought from the bottom of the ocean up to the surface, they were submitted to a huge pressure difference (250-300 atmospheres). MT gene expression might be influenced by such a pressure shock. This factor could be a new investigation field in the comprehension of the biological roles of MTs. B. azoricus mussels from Menez-Gwen vent site (850 m depth, Middle Atlantic Ridge) are able to survive in aquaria for a long period after being brought at the atmospheric pressure (Kadar et al., 2005; Hourdez, personal communication). Experimentations performed with these mussels may allow to investigate/discriminate if MT gene expression can return to a basal level close to that of $M$. edulis or be induced by a metallic stimulus. The study of these particular mussels would also allow to observe long term behavioural observations.

Our short exposures and the use of high concentrations of metals combined with the pressure stress were likely to preclude sufficient metal uptake and subcellular distribution disturbations important enough to allow significant increases of MT protein levels. 
The characterization of the regulation sequences in the promotor region of the Bathymodiolus MT genes and the study of the ability of symbionts to sequester large quantities of metals may provide answers to the questions mentioned above.

\section{Acknowledgments}

This work was supported by a grant of the Ministère de l'Éducation Nationale, de la Recherche et des Technologies, by the EU programme VENTOX: EVK3-CT-1999-00003, (coordinator: D. Dixon) and by the MDF. Our thanks go to Pr F. Lallier and Dr P. M. Sarradin, chief scientists of the HOPE and ATOS cruises for providing access to the research material. The authors gratefully acknowledge Monika Ghosh for the English corrections. 


\section{References}

Altschul, S.F., Gish, W., Miller, W., Myers, E.W., Lipman, D.J. (1990) Basic local alignment search tool. Journal of Molecular Biology 215: 403-410.

Amiard-Triquet, C., Rainglet, F., Larroux, C., Regoli, F., Hummel, H. (1998) Metallothioneins in Arctic bivalves. Ecotoxicology and Environmental Safety 41: 96-102.

Ando T., Yamamoto M., Tomiyasu T., Hashimoto J, Miura T., Nakano A., Akiba S. (2002) Bioaccumulation of mercury in a vestimentiferan worm living in Kagoshima Bay, Japan Chemosphere 49: 477-484.

Barsyte, D., White, K.N., Lovejoy, D.A. (1999) Cloning and characterization of metallothionein cDNAs in the mussel Mytilus edulis L. digestive gland. Comparative Biochemistry and Physiology: Part C 122: 287-96.

Berthet B., Mouneyrac C., Amiard J. C., Amiard-Triquet, C., Berthelot, Y., Le Hen, A., Mastain, O., Rainbow, P.S., Smith, B.D. (2003) Accumulation and soluble binding of cadmium, copper, and zinc in the polychaete Hediste diversicolor from coastal sites with different trace metal bioavailabilities. Archives of Environmental Contamination and Toxicology 45: 468-78.

Bustamante, P., Miramand, P. (2004) Interspecific and geographical variations of trace element concentrations in Pectinidae from European waters. Chemosphere 57: 1355-1362.

Canesi, L., Viarengo, A., Leonzio, C., Filippelli, M., Gallo, G. (1999) Heavy metals and glutathione metabolism in mussel tissues. Aquatic Toxicology 46: 67-76.

Cajaraville, M.P., Bebianno, M.J., Blasco, J., Porte, C., Sarasquete, C., Viarengo, A. (2000) The use of biomarkers to assess the impact of pollution in coastal environments of the Iberian Peninsula: a practical approach. Science of the Total Environment 247: 295-311.

Cherian, M.G., Howell, S.B., Imura, N., Klaassen, C.D, Koropatnick, J., Lazo, J.S., Waalkes, M.P. (1994) Role of metallothioneins in carcinogenesis. Toxicology and Applied Pharmacology 126: 1-5.

Chomczynski, P., Sacchi, N. (1987) Single-step method of RNA isolation by acid guanidinium thiocyanate-phenol-chloroform extraction. Analytical Biochemistry 162: 156-159.

Cottrell, M.T., Craig Cary, S. (1999). Diversity of dissimilatory bisulfite reductase genes of bacteria bssociated with the deep-sea hydrothermal vent polychaete annelid Alvinella pompejana. Applied and Environmental Microbiology 65: 1127-1132.

Cosson-Mannevy M.A., Wong, C.S., Cretney, W.J. (1988). Putative neoplastic disorder in mussels (Mytilus $\underline{\text { edulis }}$ ) from southern Vancouver Island waters, British Columbia. Journal of Invertebrate Pathology 44: 151-160.

Cosson, R.P., Vivier, J.P. (1995). Interactions of metallic elements and organisms within hydrothermal vents. Cahiers de Biologie Marine 38: 43-50.

Cotou, E., Vagias, C., Rapti, T., Roussis, V. (2001) Metallothionein levels in the bivalves Callista chione and Venus verrucosa from two Mediterranean sites. Z Naturforsch 56: 848-852.

Dallinger, R. (1996) Metallothionein research in terrestrial invertebrates: synopsis and perspectives. Comparative Biochemistry and Physiology Part C 113: 125-33.

Denis, F., Vachoux, C., Gauvry L., Leignel V., Salin, C., Hardivillier, Y., Cosson, R.P., Laulier, M. (2002) Characterization and expression of a Bathymodiolus sp. metallothionein gene. Cahiers de Biologie Marine 43: 329-332.

Desbruyeres, D., Biscoito, M., Caprais, J.C., Colaco, A., Comtet, T., Crassous, P., Fouquet, Y., Khripounoff, A., Le Bris, N., Olu, K., Riso, R., Sarradin, P.M., Segonzac, M., Vangriesheim, A. (2001) Variations in deep-sea hydrothermal vent communities on the Mid-Atlantic Ridge near the Azores plateau. Deep sea research Part I 48: 1325-1346. 
Devi, V. (1996) Changes in oxygen consumption and biochemical composition of the marine fouling dreissinid bivalve Mytilopsis sallei (Recluz) exposed to mercury. Ecotoxicology and Environmental Safety 33: 168-174.

Douville, E., Charlou, J.L., Oelkers, E.H., Bienvenu, P., Jove Colon, C.F., Donval, J.P., Fouquet, Y., Prieur, D., Appriou, P. (2002) The rainbow vent fluids $\left(36^{\circ} 14{ }^{\prime} \mathrm{N}\right.$, MAR): the influence of ultramafic rocks and phase separation on trace metal content in Mid-Atlantic Ridge hydrothermal fluids. Chemical Geology 184: 37-48.

Duquesne, S.J., Coll, J.C. (1995) Metal accumulation in the clam Tridacna crocea under natural and experimental conditions. Aquatic Toxicology 32(2-3): 239-253.

Engelken, J., Hildebrandt, A. (1999) cDNA cloning and cadmium-induced expression of metallothionein mRNA in the zebra mussel Dreissena polymorpha. Biochemistry and Cell Biology 77(3): 237-41.

Erk, M., Raspor, B. (2000). Advantages and disavantages of voltametric method in studying cadmium-metallothionein interactions. Cellular and Molecular Biology 46(2): 269-281.

Fiala-Medioni, A., Alayse, A.M., Cahet, G. (1986) Evidence of in situ uptake and incorporation of bicarbonate and amino acids by a hydrothermal vent mussel. Journal of Experimental Marine Biology and Ecology 96: 191-198.

Fiala-Médioni A., Rousse, N., Cosson, R.P., Boulègue, J., Sarradin, P.M. (2000) Bioaccumulation and detoxification of heavy metals in Bathymodiolus azoricus from Azores hydrothermal vents on the Mid Atlantic ridge. 7th FECS Conference on Chemistry and the Environment, Metal Speciation in the Aquatic Environment, Oporto (Portugal), pp. 30.

Garvey, J.S. (1990). Metallothionein: a potential biomonitor of exposure to environmental toxins. In: McCarthy, J.F. and Shugart, L.R., Editors. Biomarkers of Environmental Contamination, Lewis, Boca Raton, Florida, pp. 267-287.

Geffard, A., Amiard-Triquet, C., Amiard, J.C. (2005) Do seasonal changes affect metallothionein induction by metals in mussels, Mytilus edulis? Ecotoxicology and Environmental Safety 61: 209-220.

Géret, F., Rousse, N., Riso, R., Sarradin, P.M., Cosson, R.P., Biscoito M., Cary C., Dixon D., Wilson C., Sloan H. (1998) Metal compartmentalization and metallothionein isoforms in mussels from the Mid-Atlantic Ridge; preliminary approach to the fluid-organism relationship. Cahiers de Biologie Marine 39: 291-293.

Géret, F. (2000) Synthèse de métallothionéines chez deux bivalves (l'huître et la moule) en réponse à une contamination métallique par la voie directe et par la voie trophique. Thèse de doctorat, Université de Nantes, pp. 307.

Géret, F., Riso, R., Sarradin, P.M., Caprais, J. C., Cosson, R. P. (2002) Metal bioaccumulation and storage forms in the shrimp, Rimicaris exoculata, from the Rainbow hydrothermal field (Mid -Atlantic Ridge); preliminary approach to the fluid-organism relationship. Cahiers de Biologie Marine 43: 43-52.

George, S. G. (1983) Heavy metal detoxication in the mussel Mytilus edulis composition of Cdcontaining kidney granules (tertiary lysosomes). Comparative Biochemistry and Physiology Part C: Comparative Pharmacology 76(1): 53-57.

Haq, F., Mahoney, M., Koropatnick, J. (2003) Signaling events for metallothionein induction. Mutation Research/Fundamental and Molecular Mechanisms of Mutagenesis, 533: 211226.

Hardivillier, Y., Leignel, V., Denis, F., Uguen, G., Cosson, R.P., Laulier, M. (2004) Do organisms living around hydrothermal vent sites contain specific metallothioneins? The case of the genus Bathymodiolus (Bivalvia, Mytilidae). Comparative Biochemistry and Physiology Part C: Toxicology \& Pharmacology 139: 111-118.

Hall, T.A. (1999) BioEdit: a user-friendly biological sequence alignment editor and analysis program for Windows 95/98/NT. Nucleic Acids Symp. Ser 41: 95-98. 
Hennig, H.F. (1986) Metal-binding proteins as metal pollution indicators. Environmental Health Perspectives 65: 175-87.

Hensbergen, P.J., Van Velzen, M.J.M., Adi Nugroho, R., Donker, M.H., Van Straalen, N.M. (2000) Metallothionein-bound cadmium in the gut of the insect Orchesella cincta (Collembola) in relation to dietary cadmium exposure. Comparative Biochemistry and Physiology 125C: $17-24$.

Jeanthon, C., Prieur D. (1990) Susceptibility to heavy metals and characterization of heterotrophic bacteria isolated from two hydrothermal vent polychaete annelids, Alvinella pompejana and Alvinella caudata. Applied Environmental Microbiology 56: 3308-3314.

Kadar, E., Bettencourt, R., Costa, V., Serrao Santos, R., Lobo-da-Cunha, A., Dando, P. (2005) Experimentally induced endosymbiont loss and re-acquirement in the hydrothermal vent bivalve Bathymodiolus azoricus. Journal of Experimental Marine Biology and Ecology 318: 99-110.

Kershaw, W.C., Klaassen C.D. (1992) Degradation and metal composition of hepatic isometallothioneins in rats. Toxicology and Applied Pharmacology 112: 24-31.

Lam, K.L., Ko, P.W., Wong, J.K.Y., Chan, K.M. (1998) Metal toxicity and metallothionein gene expression studies in common carp and tilapia. Marine Environmental Research 46: $563-$ 566.

Langston, W.J., Bebianno, M.J., Burt, G.R. (1998) Metal handling strategies in molluscs. In: Metal Metabolism in Aquatic Environments, Langston W.J. and Bebianno M.J. Editors, Chapman \& Hall, London, pp. 219-283.

Leignel, V., Hardivillier, Y., Laulier, M. (2004) Small metallothionein genes in coastal and hydrothermal mussels. Small metallothionein MT-10 genes in coastal and hydrothermal mussels. Journal of Marine Biotechnology 7: 236-244.

Lemoine, S., Bigot, Y., Sellos, D., Cosson, R.P., Laulier, M. (2000) Metallothionein Isoforms in Mytilus edulis (Mollusca, Bivalvia): Complementary DNA Characterization and Quantification of Expression in Different Organs after Exposure to Cadmium, Zinc, and Copper. Journal of Marine Biotechnology 2: 195-203.

Lemoine, S., Laulier, M. (2003) Potential use of the levels of the mRNA of a specific metallothionein isoform (MT-20) in mussel (Mytilus edulis) as a biomarker of cadmium contamination. Marine Pollution Bulletin 46: 1450-1455.

Lonsdale, P. (1977) Clustering of suspension-feeding macrobenthos near abyssal hydrothermal vents at oceanic spreading centers. Deep-Sea Res 24: 857-863.

Lowry, O.H., Rosenbrough, N.J., Farr, A.L., Randall, R.J. (1951) Protein measurement with the Folin phenol reagent. Journal of Biological Chemistry 193: 265-275.

Mackay, E.A., Overnell, J., Dunbar, B., Davidson, I., Hunziker, P.E., Kagi, J.H., Fothergill, J.E. (1993) Complete amino acid sequences of five dimeric and four monomeric forms of metallothionein from the edible mussel Mytilus edulis. European Journal of Biochemistry 218: 183-94.

Margoshe, M., Vallee, B.L. (1957) A cadmium protein from equine kidney. Journal of the American Chemical Society 79: 4813-4819.

Marigomez, I., Soto, M., Cajaraville, M.P., Angulo, E., Giamberini, L. (2002) Cellular and subcellular distribution of metals in molluscs. Microscopy Research and Technique 56: 358-392.

Martin, M., Osborn, K., Billig, P., Glickstein, N. (1981) Toxicities of ten metals to Crassostrea gigas and Mytilus edulis embryos and Cancer magister larvae. Marine Pollution Bulletin 12: 305-308.

McKim, J.M., Choudhuri, S., Klaassen, C.D. (1992) In vitro degradation of apo-, zinc-, and cadmium-metallothionein by cathepsins B, C, and D. Toxicology and Applied Pharmacology 116: 117-124. 
Moraga, D., Mdelgi-Lasram, E., Romdhane, M.S., El Abed, A., Boutet, I., Tanguy, A., Auffret, M. (2002) Genetic responses to metal contamination in two clams: Ruditapes decussatus and Ruditapes philippinarum. Marine Environmental Research 54: 521-525.

Morris, C.A., Sturzenbaum, S., Nicolaus, B., Morgan, A.J., Harwood, J.L., Kille, P. (1999) Identification and characterisation of metallothioneins from environmental indicator species as potential biomonitors. In: Klaassen C, editor. Metallothionein IV. Basel: Birkhauser p. 621-627.

Mouneyrac, C., Amiard, J.C., Amiard-Triquet, C. (1998) Effects of natural factors: salinity and body weight on cadmium, copper, zinc and Metallothionein Like Protein levels in resident populations of oysters (Crassostrea gigas) from a polluted estuary. Marine Ecology Progress Series 162: 125-135.

Mouneyrac, C., Amiard, J.C., Amiard-Triquet, C., Cottier, A., Rainbow, P.S., Smith, B.D. (2002) Partitioning of accumulated trace metals in the talitrid amphipod crustacean Orchestia gammarellus: a cautionary tale on the use of metallothionein-like proteins as biomarkers. Aquatic Toxicology 57: 225-242.

Neff, J.M. (1985) Use of biochemical measurements to detect pollutant-mediated damage to fish. In: Cardwell, R.D., Purdy, R. and Bahner, R.C., Editors. Aquatic Toxicology and Hazard Assessment: Seventh Symposium ASTM STP 854, American Society for Testing and Materials, Philadelphia, Pa, pp. 155-183.

Olafson, R.W., Sim, R.G. (1979) An electrochemical approach to quantification and characterization of metallothioneins. Analytical Biochemistry 100: 343-351.

Olsson, P.E., Kille, P. (1997) Functional comparison of the metal-regulated transcriptional control regions of metallothionein genes from cadmium-sensitive and tolerant fish species. Biochimica and Biophysica Acta 1350: 325-334.

Palmiter, R.D. (1995) Constitutive Expression of Metallothionein-III (MT-III), but Not MT-I, Inhibits Growth When Cells Become Zinc Deficient. Toxicology and Applied Pharmacology 135(1): 139-146.

Pedersen, K.L., Pedersen, S.N., Hojrup, P., Andersen, J.S., Roepstorff, P., Knusden, J., Depledge, M.H. (1994) Purification and characterization of a calcium-induced metallothionein from the shore crab Carcinus maenas. Biochemical Journal 297: 609614.

Petering, D.H., Goodrich, M., Hodgman, W. (1990). Metal-binding proteins and peptides for the detection of heavy metals in aquatic organisms. In: McCarthy, J.F. and Shugart, L.R., Editors, 1990. Biomarkers of Environmental Contamination, Lewis, Boca Raton, Florida, pp. 239-254.

Piscator, M. (1964). On cadmium in normal human kidneys together with a report on the isolation of metallothionein from levers of cadmium-exposed rabbits. Nord. Hyg. Tidskr. 45: 76-82.

Raspor, B., Pavic, J., Kozar, S., Kwokal, Z., Paic, M., Odzak, N., Ujevic, I., Kljakovic, Z. (1999) Assessment of metal exposure of marine edible mussels by means of biomarker. In: Klaassen C., editor. Metallothionein IV. Basel (Switzerland): Birkhauser p. 629-632.

Roesijadi, G., Hall, R.E. (1981). Characterization of mercury-binding proteins from the gills of marine mussels exposed to mercury. Comparative Biochemistry and Physiology Part C 70: 59-64.

Roméo, M., Frasila, C., Gnassia-Barelli, M., Damiens, G., Micu, D., Mustata, G. (2005) Biomonitoring of trace metals in the Black Sea (Romania) using mussels Mytilus galloprovincialis. Water Research 39: 596-604.

Rousse, N., Boulegue, J., Cosson, R.P., Fiala Medioni, A. (1998) Bioaccumulation of metal within the hydrothermal mytilidae Bathymodiolus sp. from the Mid-Atlantic Ridge. Oceanologica Acta 21: 597-607. 
Sarradin, P.M., Caprais, J.C., Riso, R., Kerouel, R., Aminot, A. (1999) Chemical environment of the hydrothermal mussel communities in the Lucky Strike and Menez Gwen vent fields, Mid Atlantic Ridge. Cahiers de Biologie Marine 40: 93-104.

Serafim, M.A., Bebianno, M.J. (2001) Variation of metallothionein and metal concentrations in the digestive gland of the clam Ruditapes decussatus: sex and seasonal effects. Environnement Toxicology Chemistry 20: 544-52.

Stegeman, J.J., Brouwer, M., DiGiulio, R.T., Forlin, L., Fowler, B.A., Sanders, B.M., Van Veld Brouwer, P.A. (1992). Molecular responses to environmental contamination: enzyme and protein systems as indicators of chemical exposure and effect. In: Huggett, R.J., Kimerle, R.A., Mehrle, P.M. and Bergman, H.L., Editors, 1992. Biomarkers: biochemical, physiological, and histological markers of anthropogenic stress, Lewis Publishers, Chelsea, MI, pp. 235-335.

Sturzenbaum, S.R., Kille, P., Morgan, A.J. (1998) The identification, cloning and characterization of earthworm metallothionein. FEBS Letters 431: 437-442.

Thompson, J.A.J., Cosson, R.P. (1984) An improved electrochemical method for the quantification of metallothioneins in marine organisms. Marine Environmental Research 11: 137-152.

Thompson, J.D., Higgins, D.G., Gibson, T.J. (1994) CLUSTAL W: improving the sensitivity of progressive multiple sequence alignment through sequence weighting, positions-specific gap penalties and weight matrix choice. Nucleic Acids Research 22: 4673-4680.

Viarengo, A., Palmero, S., Zanicchi, G., Capelli, R., Vaissiere, R., Orunesu, M. (1985) Role of metallothioneins in $\mathrm{Cu}$ and $\mathrm{Cd}$ accumulation and elimination in the $\mathrm{g}$ gill and digestive gland cells of Mytilus galloprovincialis lam. Marine Environmental Research 16: 23-36.

Viarengo, A., Canesi, L., Pertica, M., Mancinelli, G., Orunesu, M. (1988) Biochemical characterization of a copper-thionein involved in $\mathrm{Cu}$ accumulation in the lysosomes of the digestive gland of mussels exposed to the metal, Marine Environmental Research 24: 163-166.

Yap, C.K., Ismail, A., Omar, H., Tan, S.G. (2004) Toxicities and tolerances of $\mathrm{Cd}, \mathrm{Cu}, \mathrm{Pb}$ and $\mathrm{Zn}$ in a primary producer (Isochrysis galbana) and in a primary consumer (Perna viridis). Environment International 29: 1097-1104. 
$\underline{\text { A: }}$

Act-1

5'- CTG GGA ATG ACA TGG AGG AGA -3' (forward)

Act-2

5'- ACA TCT GCT GGA AGG TGG AC -3' (reverse).

$\underline{\text { B: }}$

Hist-1

5'- ATG ACT GGT CGT GGT AAA GG -3' (forward)

Hist-2

5'- TAA CCG CCA AAT CCA TAG AG -3' (reverse).

C:

28S-1

5'- AAC ATG TGC GCG AGT CAT G -3' (forward)

$28 \mathrm{~S}-2$

5'- CTT TCG CCC CTA TAC CCA AG -3' (reverse).

Figure 1. Nucleotide sequences $\left(5^{\prime}-3^{\prime}\right)$ of the PCR primers. A: Primers used for Actin-1 amplification; $\underline{\text { B: }}$ Primers used for Histone-4 amplification; $\underline{\mathbf{C}}$ : Primers used for $28 \mathrm{~S}$ amplification 
Bathymodiolus thermophilus Bathymodiolus azoricus Nytilus galloprovincialis Crassostrea virginica Crassostrea gigas Placopecten magellanicus

Bathymodiolus thermophilus Bathymodiolus azoricus Mytilus galloprovincialis Crassostrea virginica Crassostrea gigas placopecten magellanicus

Bathymodiolus thermophilus Bathymodiolus azoricus Mytilus galloprovincialis Crassostrea virginica Crassostrea gigas Placopecten magellanicus

Bathymodiolus thermophilus Bathymodiolus azoricus Mytilus galloprovincialis Crassostrea virginica Crassostrea gigas Placopecten magellanicus

Bathymodiolus thermophilus Bathymodiolus azoricus Mytilus galloprovincialis Crassostrea virginica Crassostrea gigas Placopecten magellanicus

Bathymodiolus thermophilus Bathymodiolus azoricus Mytilus galloprovincialis Crassostrea virginica Crassostrea gigas

placopecten magellanicus

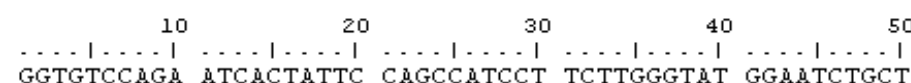
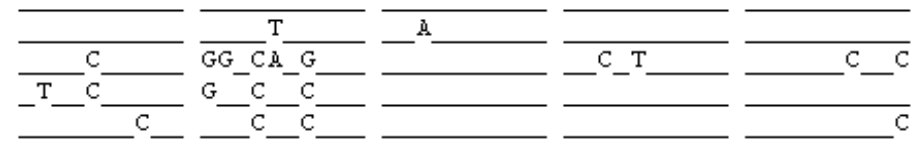

$\begin{array}{ccccc}60 & 70 & 80 & 90 & 100\end{array}$ GGTATCCATG AAACCACATA CaACAGTaTC ATGAAGTGCG ACGTCGaCaT

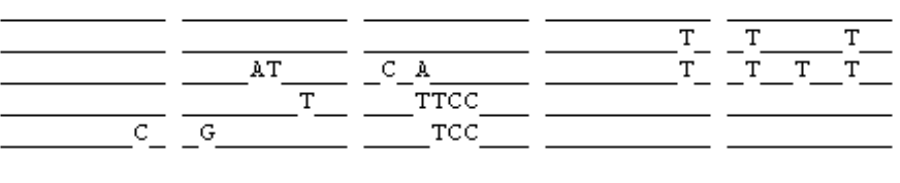

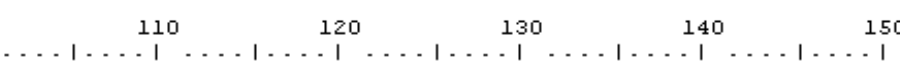
CCGTAMGGAC TTGTAC.GCC AACACCGTTT TGTCTGGTGG TACCACCATG

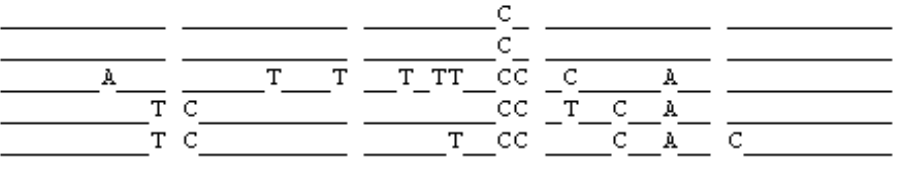

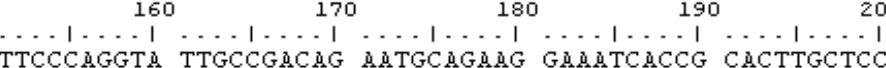

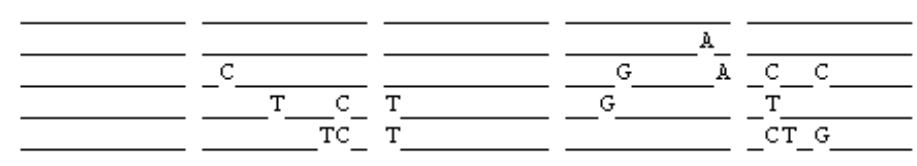

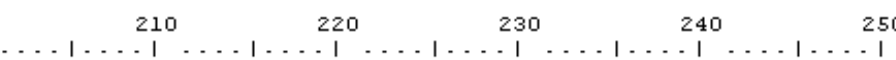

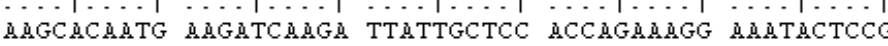
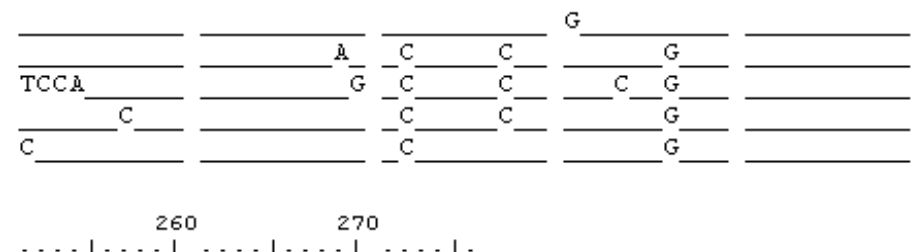

TCTGGATCGG TGGTTCCATC TTAGCT

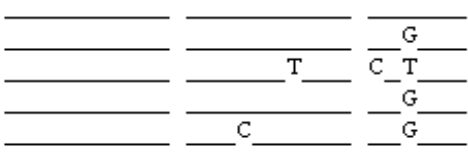

Figure 2. The actin-1 nucleotide sequences of Bathymodiolus azoricus (accession no. AJ786402) and Bathymodiolus thermophilus (accession no. AJ786403) were aligned with the actin-1 sequences of Mytilus galloprovincialis (accession no. AF157491), Crassostrea virginica (accession no. X75894), Crassostrea gigas (accession no. AB071191) and Placopecten magellanicus (accession no. U55046) using ClustalW 1.83 (Thompson et al., 1994) and edited using the multiple sequence alignment editor Bioedit (Hall et al., 1999). 


\section{A:}

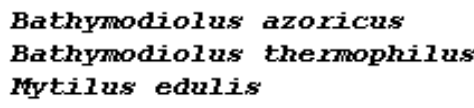

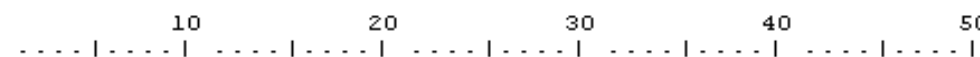
ÄAGGACTTG GAAMGGGAGG CGCTAMGCGT CACCGACAMG TTTTGCGTGA

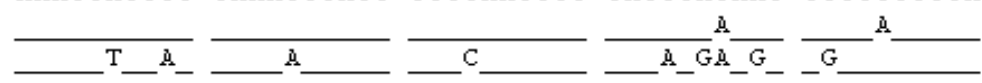

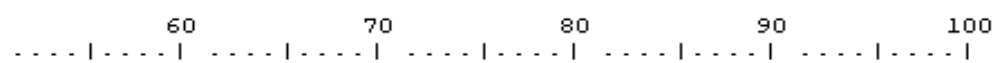
TAACATTCAG GGTATCACCA AGCCCGCTAT TCGTCGCTTA GCTCGACGAG

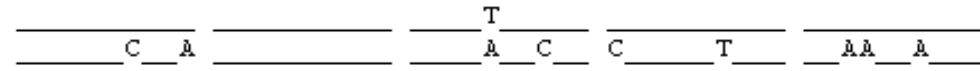

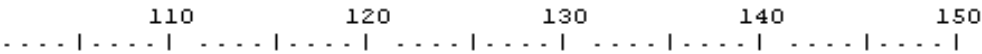
GTGGTGTCA GCGTATCTCT GGCTTGATCT ATGAGGAGAC CCGAGGTGTC

\begin{tabular}{|c|c|c|c|c|c|c|}
\hline & & & & & & $\overline{\mathrm{AC}} \quad \mathrm{C}$ \\
\hline
\end{tabular}

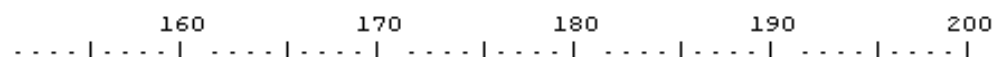
CTTAMGGTCT TCCTTGAGA TGTCATCCGT GATGCTGTCA CCTACACTGA

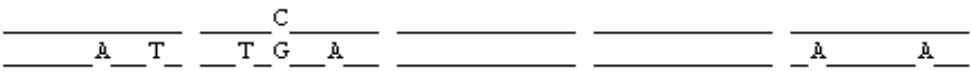

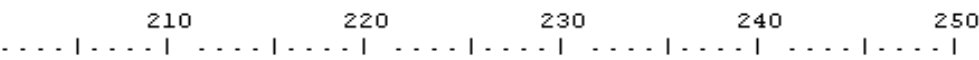

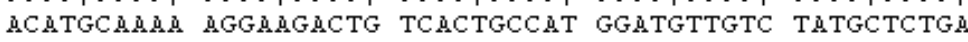

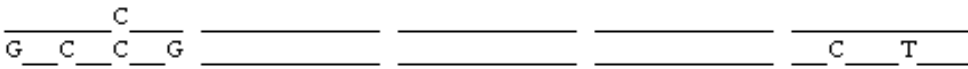

Bathymodiolus azoricus is

Bathymodiolus thermophilus

Mtilus edulis

B:

Bathomodiolus themmophilus

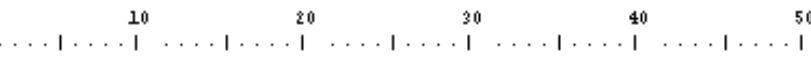

Bathimodiolus axoricus

Kytilus ednlis

KGLGKGGAKR HRKVLRDNIQ GITKPAIRRL ARRGGVKRIS GLIYEETRGV

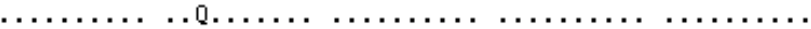

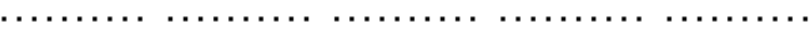

Bathymodiolus thermophilus Bathpmodiolus axoricus

rytilus edmis

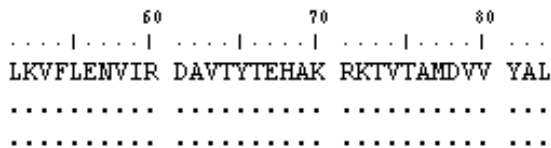

Figure 3. A: The histone-4 nucleotide sequences of $B$. azoricus (accession no. $\underline{\mathbf{A J 7 8 6 4 0 5}}$ ) and $B$. thermophilus (accession no. $\underline{\mathbf{A J 7 8 6 4 0 4}}$ ) were aligned with histone-4 sequences of Mytilus edulis (accession no. AF506076) using ClustalW 1.83 (Thompson et al., 1994) and edited using the multiple sequence alignment editor Bioedit (Hall, 1999) B: The proteic histone-4 protein sequences of B. azoricus and B. thermophilus were translated in silico and aligned with histone-4 sequences of $M$. edulis (accession no. $\underline{\text { AF506076) }}$ using the same tools. 
Bathpmodiolus thermophilus Bathmodiolus azoricus Modiolus nipponicus Nytilus edmis lytilus galloprovincialis

Bathymodiolus thermophilus Bathymodiolus azoricus Modiolus nipponicus Nytilus echis lytilus galloprovincialis

Bathymodiolus themophilus Bathrmodiolus azoricus Modiolus nipporicus Nytilus edmis

lytilus galloprovincialis

Bathymodiolus thermophilus Bathymodiolus azoricus Modiolus nipponicus Nytilus edmis Nytilus galloprovincialis

Bathymodiolus thermophilus Bathymodiolus azoricus Modiolus nipponicus Nytilus echlis Nytilus galloprovincialis

Bathymodiolus themophilus Bathymodiolus azoricus Modiolus nipponicus Nytilus edmis

Nytilus galloprovincialis $\ldots 1 \ldots 1^{10} \ldots 1 \ldots 1^{20} \ldots 1 \ldots 1^{30} \ldots 1 \ldots 1^{40} \ldots 1 \ldots 1$

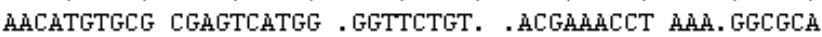

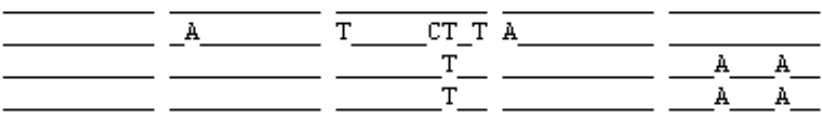

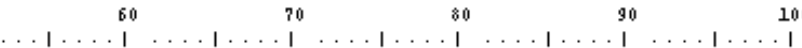
ATGGAAAGTGA AGGTCAACCT CCGGTCGGCC . TÄG. . . GT AGGATCCCCG
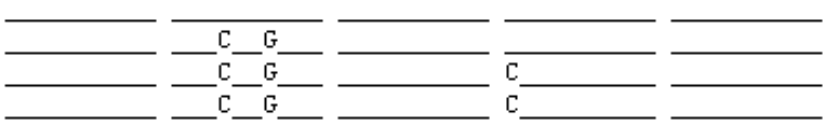

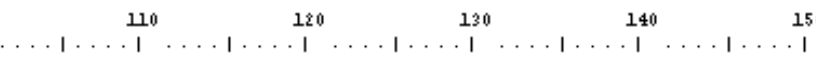
... TCGAG ..... GGGC GCACTACCGG CCCGTCT. CG ACC. ACATTG

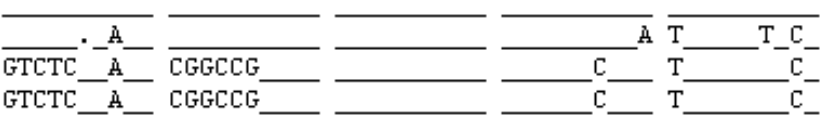

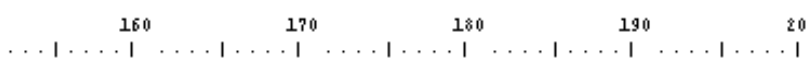
TTGGTGG... . .GGCGGAGC AAGAGCGTAC ACGTTGGGAC CCGAAAGATG

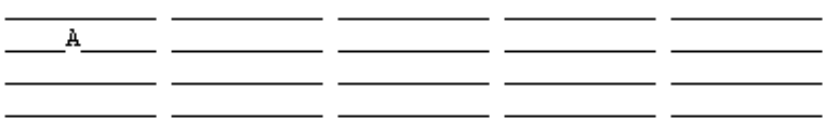

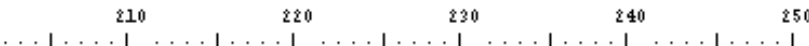

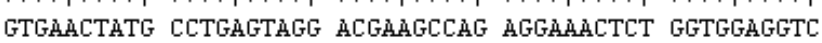

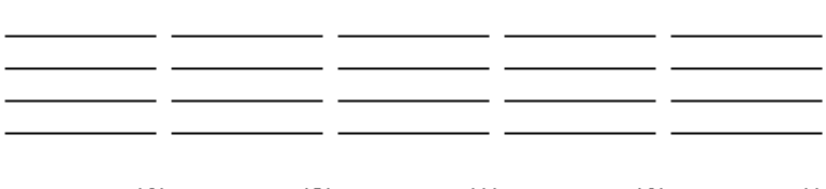
$\left.\left.\ldots 1 \ldots\right|^{260} \ldots 1 \ldots\right|^{270} \ldots 1 \ldots 1^{280} \ldots 1 \ldots 1^{280} \ldots 1 \ldots 1$ CGTAGCGATT CTGACGTGCA A. .ATCGATC GTCAAACTTG GGTATAGGGG

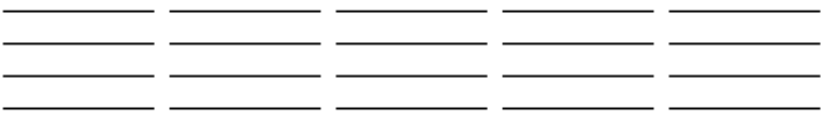

Bathamodiolus themophilus CGAAB Bathymodiolus axoricus Modiolus nipponicus

Nytilus eanis

Kytilus galloprovincialis

Figure 4. The 28S nucleotide sequences of Bathymodiolus azoricus (accession no. $\underline{\mathbf{A J 7 8 6 4 0 6}}$ ) and Bathymodiolus thermophilus (accession no. $\underline{\mathbf{A J 7 8 6 4 0 7}}$ ) were aligned with 28S sequences of Modiolus nipponicus (accession no. A $\overline{\mathbf{B 1 0 3 1 2 5}}$ ), Mytilus edulis (accession no. AF120587), and Mytilus galloprovincialis (accession no. AB103129), using ClustalW 1.83 (Thompson et al., 1994) and edited using the multiple sequence alignment editor Bioedit (Hall, 1999) 

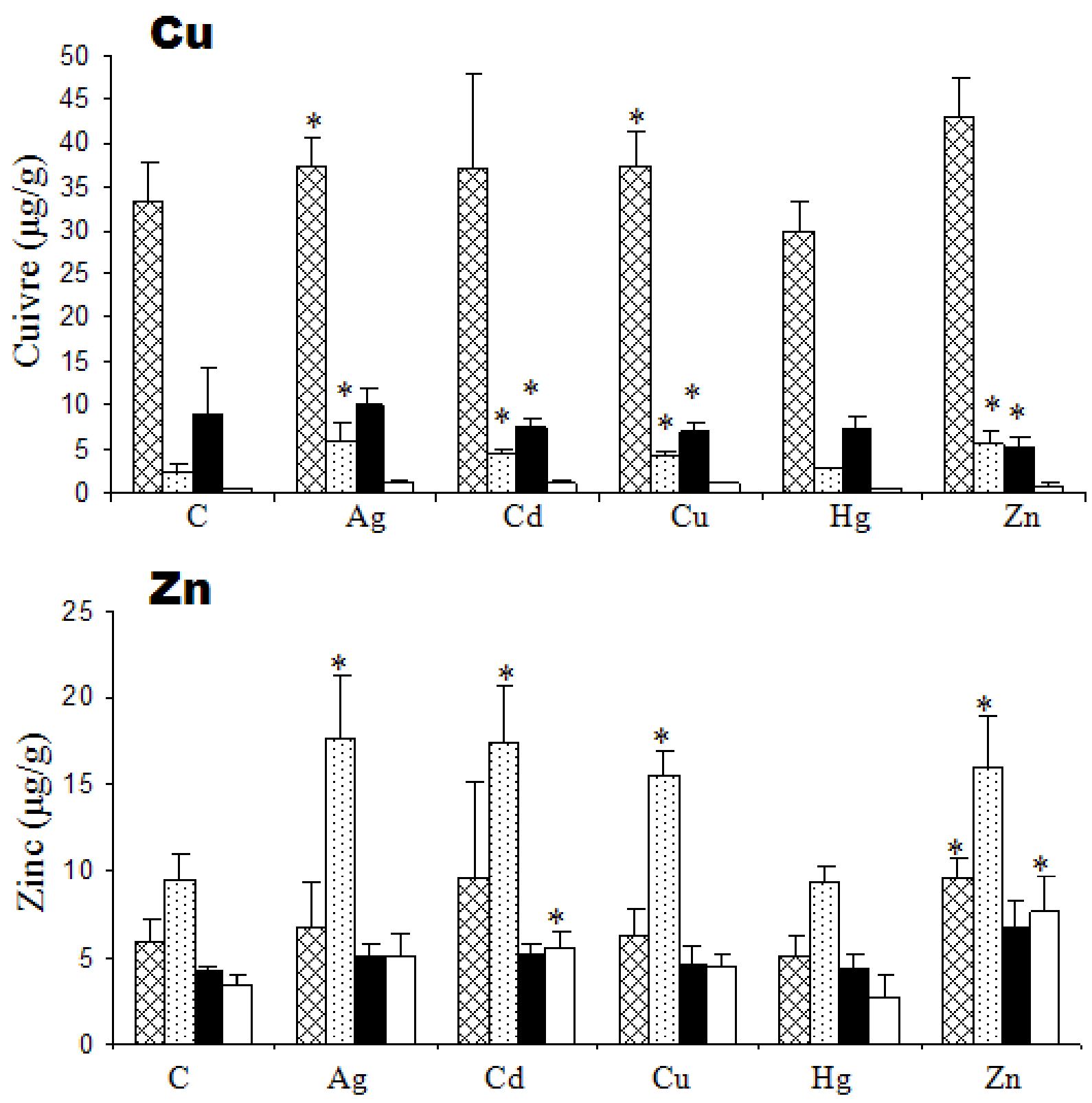

Figure 5. Subcellular distribution of metals $(\mathrm{Cu}, \mathrm{Zn})$ in soluble and pellet fractions obtained after the centrifugation of gills ( $\mathbb{X}_{\text {: }}$ insoluble fraction, 1 : soluble fraction) and mantle ( $\boldsymbol{\square}$ : insoluble fraction and $\square$ : soluble fraction) homogenates (mean \pm S.D., $n=10$, $\mu \mathrm{g} \mathrm{g}^{-1}$ w.w.). Asterisks indicate significant differences $(\mathrm{P} \leq 0.05)$ between control $(\mathrm{C})$ and exposed mussels ( $\mathrm{Ag}, \mathrm{Cd}, \mathrm{Cu}, \mathrm{Hg}, \mathrm{Zn}$ ) as determined by Kruskal-Wallis tests. 

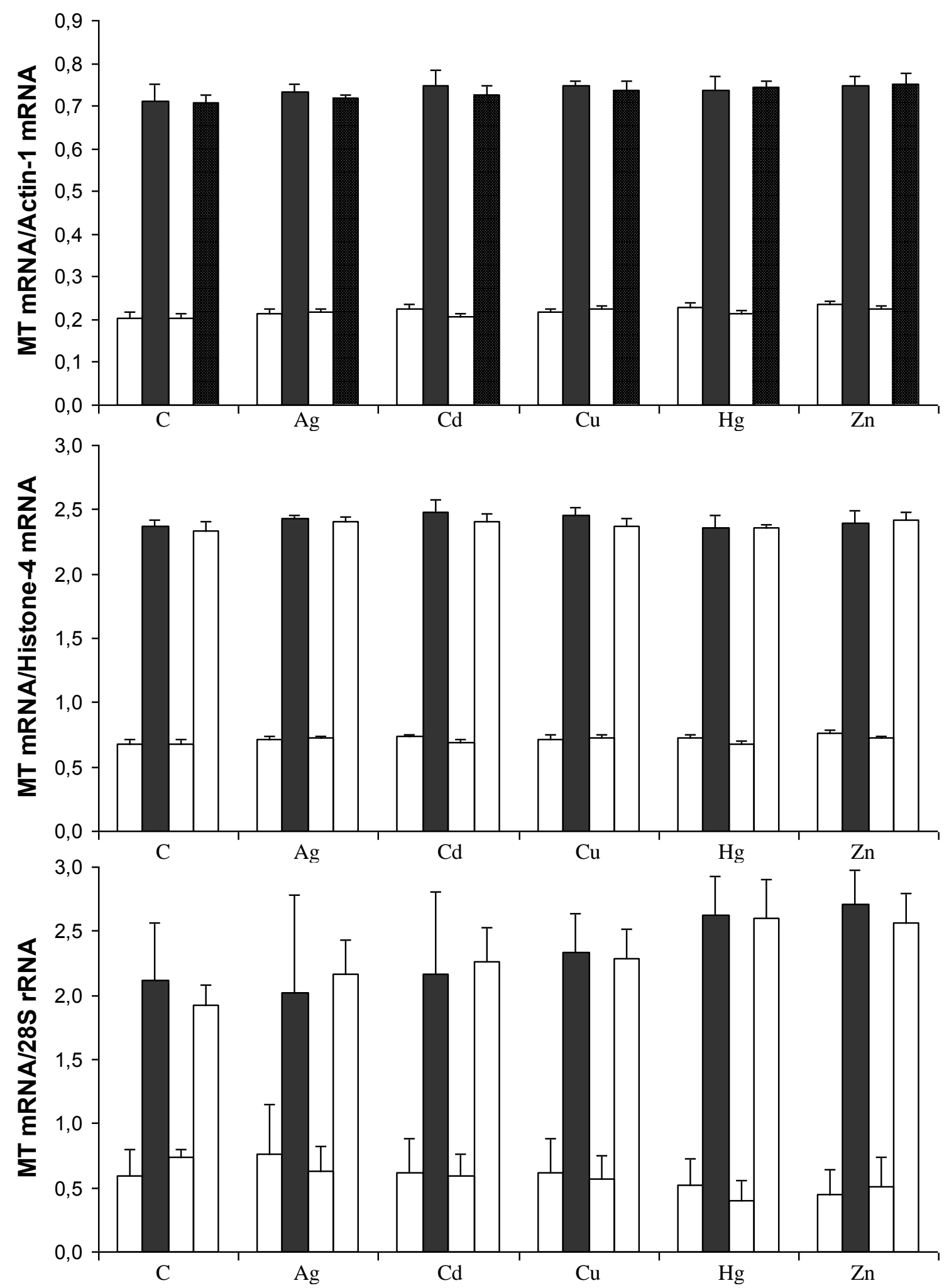

Figure 6. Normalised levels of MT mRNA in the gills ( $\square$ : MT-10 and $\square$ : MT-20) and in the mantle (: MT-10 and : MT-20) of Bathymodiolus thermophilus at the atmospheric pressure. Mussels were exposed to various metals at different concentrations (see table 3) during 44 hours. $\mathrm{C}$ is for Control. The data represent means \pm S.D. with $n=10$. 


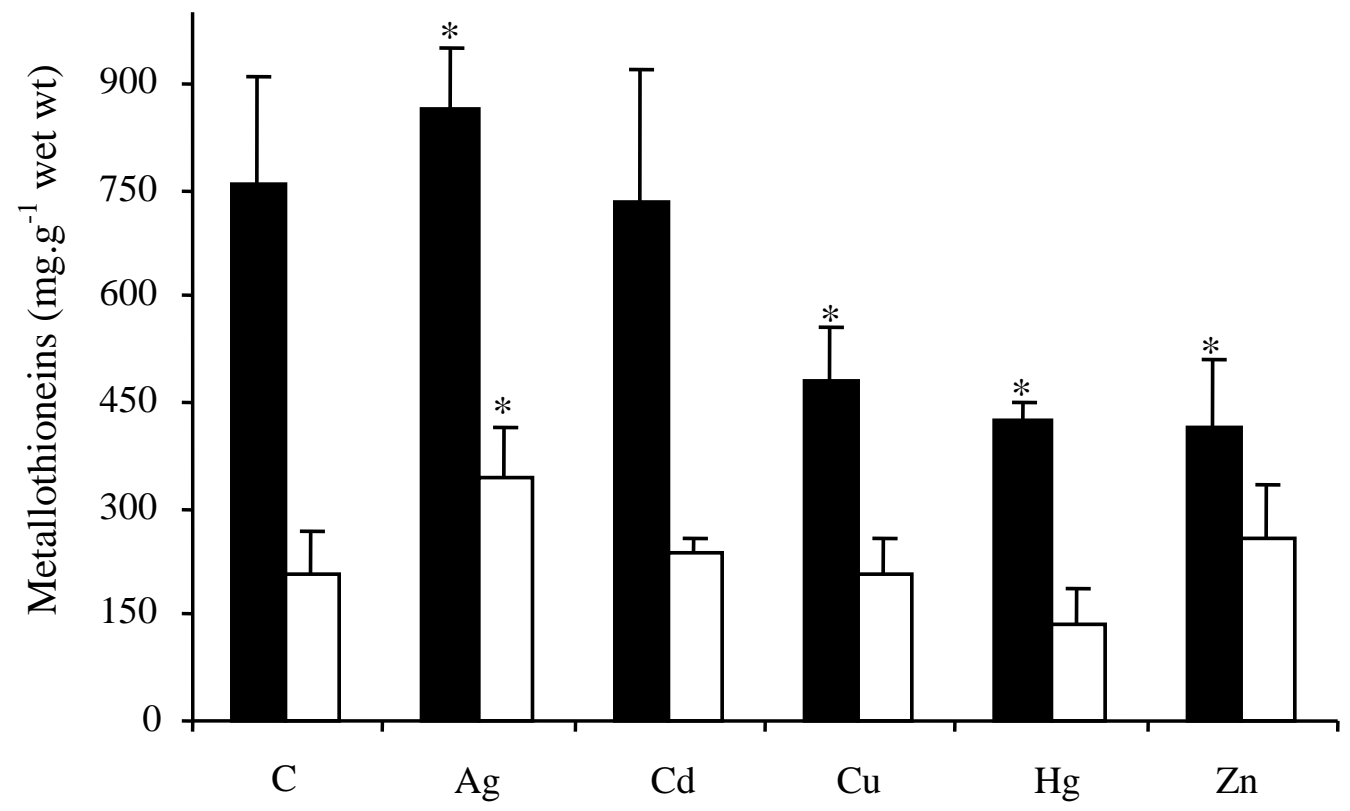

Figure 7. Levels of MT protein in the gills (black bars) and in the mantle (white bars) of Bathymodiolus thermophilus at the atmospheric pressure. The data represent means \pm S.D. with $\mathrm{n}=10$. Asterisks indicate significant differences $(\mathrm{P} \leq 0.05)$ between control $(\mathrm{C})$ and treated animals as determined by Kruskal Wallis tests. 
Table 1. Total levels of metals ( $\mu \mathrm{g} \cdot \mathrm{g}^{-1}$ w.w., $\mathrm{n}=4 \pm$ S.D.) in mussel tissues of control specimens and those exposed for $44 \mathrm{~h}$ to monometallic solutions of $\mathrm{Ag}, \mathrm{Cd}, \mathrm{Cu}, \mathrm{Hg}$ and $\mathrm{Zn}$.

\begin{tabular}{ccccccc}
\cline { 3 - 7 } & & $\mathrm{Ag}$ & $\mathrm{Cd}$ & $\mathrm{Cu}$ & $\mathrm{Hg}$ & $\mathrm{Zn}$ \\
\hline \multirow{3}{*}{ Gills } & Control & 3.90 & 0.49 & 35.81 & 0.34 & 15.30 \\
& Exposed & 4.58 & 1.21 & 41.68 & 0.30 & 25.53 \\
& & & & & & \\
\multirow{3}{*}{ Mantle } & Control & 3.71 & 0.07 & 9.38 & 0.48 & 7.61 \\
& Exposed & 4.76 & 0.23 & 7.91 & 0.31 & 14.33 \\
\hline
\end{tabular}

Table 2. Average levels of metallothioneins ( $\mu \mathrm{g} . \mathrm{g}^{-1}$ w.w.) in littoral molluscs (Géret, 2000) and in hydrothermal modioles (controls).

\begin{tabular}{lcc}
\hline \multicolumn{1}{c}{ Species } & Gills & Mantle \\
\hline Mytilus edulis & 202 & 386 \\
Crassostrea gigas & 115 & 123 \\
Bathymodiolus thermophilus & 240 & 625 \\
\hline
\end{tabular}

Table 3. Metal concentrations used in the exposures of B. thermophilus and natural metal concentrations occurring at hydrothermal vent fields.

\begin{tabular}{cccc}
\hline Metal & $\begin{array}{c}\text { Exposure concentrations } \\
\left(\mu \mathrm{g} . \mathrm{L}^{-1}\right)\end{array}$ & Vent field concentration $\left(\mu \mathrm{g} . \mathrm{L}^{-1}\right)$ & Reference \\
\hline $\mathrm{Ag}$ & 20 & 0.46 (Menez Gwen) & Douville et al., 2002 \\
$\mathrm{Cd}$ & 200 & 0.25 (Menez Gwen) & Douville et al., 2002 \\
$\mathrm{Cu}$ & 40 & 0.12 (Menez Gwen) & Douville et al., 2002 \\
$\mathrm{Hg}$ & 20 & 0.005 (Kagoshima Bay) & Ando et al., 2002 \\
$\mathrm{Zn}$ & 1000 & 131 (Menez Gwen) & Douville et al., 2002 \\
\hline
\end{tabular}


Table 4. Metal LD50 in close species from Bathymodiolus thermophilus.

\begin{tabular}{cccc}
\hline Metal & LD50 $\left(\mathrm{mg} . \mathrm{L}^{-1}\right)$ & Species & Reference \\
\hline $\mathrm{Ag}$ & 14 & Mytilus edulis & Martin et al., 1981 \\
$\mathrm{Cd}$ & 1.53 & Perna viridis & Yap et al., 2004 \\
$\mathrm{Cu}$ & 0.25 & Perna viridis & Yap et al., 2004 \\
$\mathrm{Hg}$ & 0.25 & Mytilopsis sallei & Devi, 1996 \\
$\mathrm{Zn}$ & 3.20 & Perna viridis & Yap et al., 2004 \\
\hline
\end{tabular}

